\title{
Sheep production during the rainy season in marandu palisadegrass swards previously utilized under deferred grazing
}

\author{
[Produção de ovinos no período das águas em pastagens com capim-marandu previamente \\ utilizadas sob pastejo diferido] \\ D.O.C. Sousa ${ }^{1}$, M.E.R. Santos ${ }^{1}$, D.M. Fonseca ${ }^{2}$, G.L. Macedo Junior ${ }^{1}$, S.P. Silva ${ }^{1}$ \\ ${ }^{1}$ Faculdade de Medicina Veterinária - Universidade Federal de Uberlândia - Uberlândia, MG \\ ${ }^{2}$ Universidade Federal de Viçosa - Viçosa, MG
}

\begin{abstract}
The objective of this study was to evaluate the effects of Brachiaria brizantha cv. Marandu syn. Urochloa brizantha cv. Marandu (Marandu palisadegrass) in late winter on pasture structure, apparent selectivity, and sheep production during spring and early summer. The conditions of deferred pastures at the end of winter were: low $(15.1 \mathrm{~cm}$ and $4600 \mathrm{~kg} / \mathrm{ha}$ of DM), medium $(23.2 \mathrm{~cm}$ and $5940 \mathrm{~kg} / \mathrm{ha}$ of DM), high $(31.4 \mathrm{~cm}$ and $7640 \mathrm{~kg} / \mathrm{ha}$ of DM) and high/mowed $(31.3 \mathrm{~cm}$ and $7200 \mathrm{~kg} / \mathrm{ha}$ of DM, mowed to $8 \mathrm{~cm})$. The experiment was conducted in split plot design (sward conditions at the end of winter: low, medium, tall and tall/lowered) during time (early, middle and late spring/summer) and completely randomized design with three replications. The percentages of live leaf laminae in available forage and in simulated grazing samples were higher in tall/lowered sward and lower in high sward, oppositely to percentage of dead tissue. Only at the beginning of the grazing period the high/lowered sward had lower forage mass and bulk density. This remained high in high sward during all the grazing period. The sheep performance and the animal production per area were higher in low sward and lower in tall swards. The low sward has better structure and higher sheep production starting at spring. The lower of the marandu palisade grass at late winter improves this structure and increases sheep production during spring and early summer.
\end{abstract}

Keywords: Animal selectivity, Brachiaria brizantha syn, Urochloa brizantha, mowing, sward structure

\section{RESUMO}

Objetivou-se avaliar os efeitos da condição do pasto diferido de Brachiaria brizantha cv. Marandu syn. Urochloa brizantha $\mathrm{cv}$. Marandu (capim-marandu) no fim do inverno sobre a estrutura do pasto, a seletividade aparente e a produção de ovinos durante a primavera e o início do verão. As condições dos pastos diferidos no fim do inverno foram: baixo $(15,1 \mathrm{~cm}$ e $4.600 \mathrm{~kg} / \mathrm{ha}$ de MS), médio (23,2cm e $5.940 \mathrm{~kg} / \mathrm{ha}$ de MS), alto $(31,4 \mathrm{~cm}$ e $7.640 \mathrm{~kg} / \mathrm{ha}$ de MS) e alto/roçado $(31,3 \mathrm{~cm}$ e $7.200 \mathrm{~kg} / \mathrm{ha}$ de $M S$, rebaixado para $8 \mathrm{~cm}$ ). O experimento foi conduzido em esquema de parcela (condições dos pastos ao fim do inverno: baixo, médio, alto e alto/roçado) subdividida no tempo (início, meio e fim da primavera/verão) e delineamento inteiramente ao acaso, com três repetições. Os percentuais de lâmina foliar viva na forragem disponível e na amostra de simulação de pastejo foram maiores no pasto alto/roçado e menores no pasto alto, contrariamente ao percentual de tecido morto. Apenas no início do período de pastejo, o pasto alto/roçado apresentou menores massa e densidade volumétrica de forragem. Esta se manteve alta no pasto alto durante todo o período de pastejo. No início do período de pastejo, os pastos apresentaram pior composição morfológica na FD. O desempenho dos ovinos e a produção animal por área foram maiores no pasto baixo e menores no pasto alto. O pasto baixo, no fim do inverno, apresenta melhor estrutura e maior produção de ovinos a partir da primavera. A roçada do pasto de capim-marandu no fim do inverno melhora sua estrutura e aumenta a produção animal durante a primavera e o início do verão.

Palavras-chave: Brachiaria brizantha syn, Urochloa brizantha, estrutura do pasto, roçada, seletividade animal

Recebido em 6 de setembro de 2016

Aceito em 10 de maio de 2017

E-mail: diogoolimpio@hotmail.com 


\section{INTRODUCTION}

The deferment of the pastures is a generally a low-cost and relatively easy strategy, which may allow adequate supply of pasture to the herd's demand during the winter (Canto et al., 2002; Euclides et al., 2007). However, deferred pastures with high forage mass at the end of winter may have their regrowth compromised in the spring due to shading at the base of the plants, which inhibits tilling (Santos et al., 2011; Santana et al., 2014). High amounts of stems and dead forage in late winter, common in deferred pastures, may also remain interspersed with spring regrowing plants, contributing to worsen pasture structure and hinder selective grazing of animals.

Thus, in order to avoid regrowth delay, improve pasture structure, and facilitate selective grazing of animals during spring and summer, it is appropriate that the previously deferred pasture is low at the end of winter. However, mowing the high deferred pasture can promote the elimination of old and dead tillers, as well as stimulate their renewal (Souza et al., 2015). Posteriorly to the mowing, the pasture structure would facilitate the intake by the grazing animals during spring and summer.

It is important to improve the structure of the pasture, understood as the arrangement of the organs of the aerial part of the plants in a community (Laca e Lemaire, 2000), due to its effects on intake (Fonseca et al., 2012) and, therefore, on grazing performance (Poppi et al., 1987). In this sense, the pasture with a higher percentage of live leaf favors the intake by the animal, since the live leaf presents less resistance to seizure (Nave et al., 2010) and has better nutritive value (Santos et al., 2008), when compared to the stem.

The objective of this study was to evaluate the effects of mowing and the condition of late winter deferred pastures of Brachiaria brizantha cv. Marandu syn. Urochloa brizantha cv. Marandu on pasture structure, apparent selectivity and sheep production during spring and early summer.

\section{MATERIAL AND METHODS}

The Federal University of Uberlândia Institutional Animal Care and Use Committee approved all procedures involving the animals of this study (Protocol number: 031/13).

The experiment was conducted from January, 2013 to February, 2014 at the Capim Branco Experimental Farm, School of Veterinary Medicine, at the Federal University of Uberlândia, in Uberlândia, Brazil. The geographical coordinates of the site are $18^{\circ} 30^{\prime}$ south latitude and $47^{\circ} 50^{\prime}$ west longitude of Greenwich, and its altitude is $776 \mathrm{~m}$. The climate of the region is tropical Cwa-type (Köppen, 1948), with mild and dry winter, and well defined dry and rainy seasons. The average annual temperature is $22.3^{\circ} \mathrm{C}$. The average annual rainfall is $1,584 \mathrm{~mm}$.

The experimental area consisted of a pasture of Brachiaria brizantha cv. Marandu syn. Urochloa brizantha $\mathrm{cv}$. Marandu (marandu palisadegrass) established in 2000, with twelve paddocks (experimental units), with $800 \mathrm{~m}^{2}$ each, plus a reserve area, totaling approximately two hectares.

The climatic conditions during the experimental period were monitored by the Meteorological Station, located approximately $100 \mathrm{~m}$ from the experimental area (Figure 1). Based on this information, the soil water extract was calculated during the experiment (Figure 2).

Soil samples were taken from each experimental unit to analyze the fertility level in the $0-20 \mathrm{~cm}$ layer, presenting, on average, the following characteristics: $\mathrm{pH}$ in $\mathrm{H}_{2} \mathrm{O}$ : 6.1; $\mathrm{P}: 4.5$ (Mehlich1) and $\mathrm{K}: 138.8 \mathrm{mg} / \mathrm{dm}^{3} ; \mathrm{Ca}^{2+}: 5.1 ; \mathrm{Mg}^{2+}: 1.9$ and $\mathrm{Al}^{3+}: 0 \mathrm{cmol}_{\mathrm{c}} / \mathrm{dm}^{3}$. Based on these results and according to the recommendations of Cantarutti et al. (1999) for a medium level technological system, $55 \mathrm{~kg} /$ ha of $\mathrm{P}_{2} \mathrm{O}_{5}$ ( single superphosphate) and $50 \mathrm{~kg} /$ ha of $\mathrm{N}$ (urea) were applied in January 2013. Another application of $70 \mathrm{~kg} / \mathrm{ha}$ of $\mathrm{N}$ occurred on $03 / 15 / 2013$. 


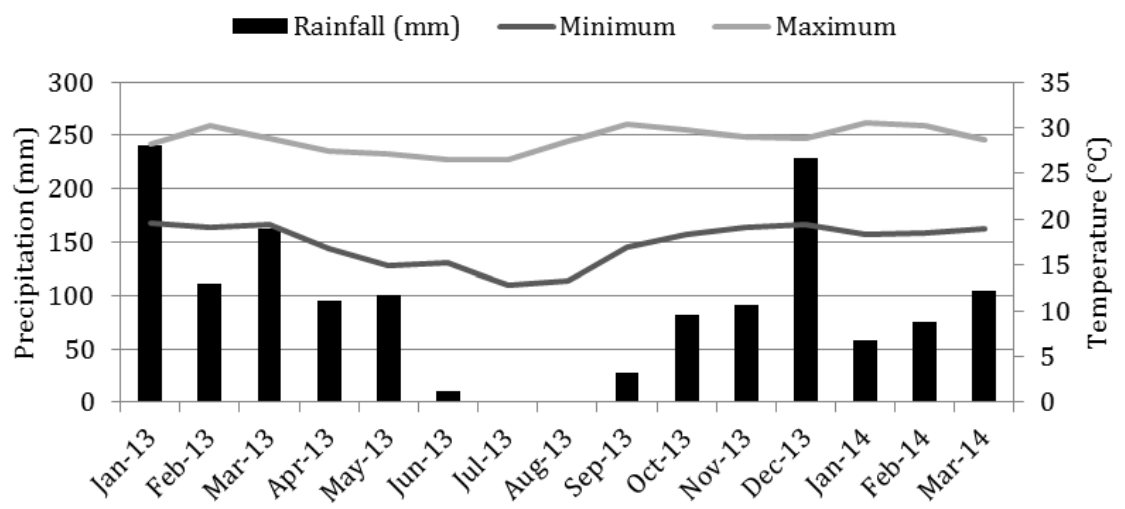

Figure 1. Monthly average minimum and maximum daily temperatures and rainfall from January 2013 to March 2014.

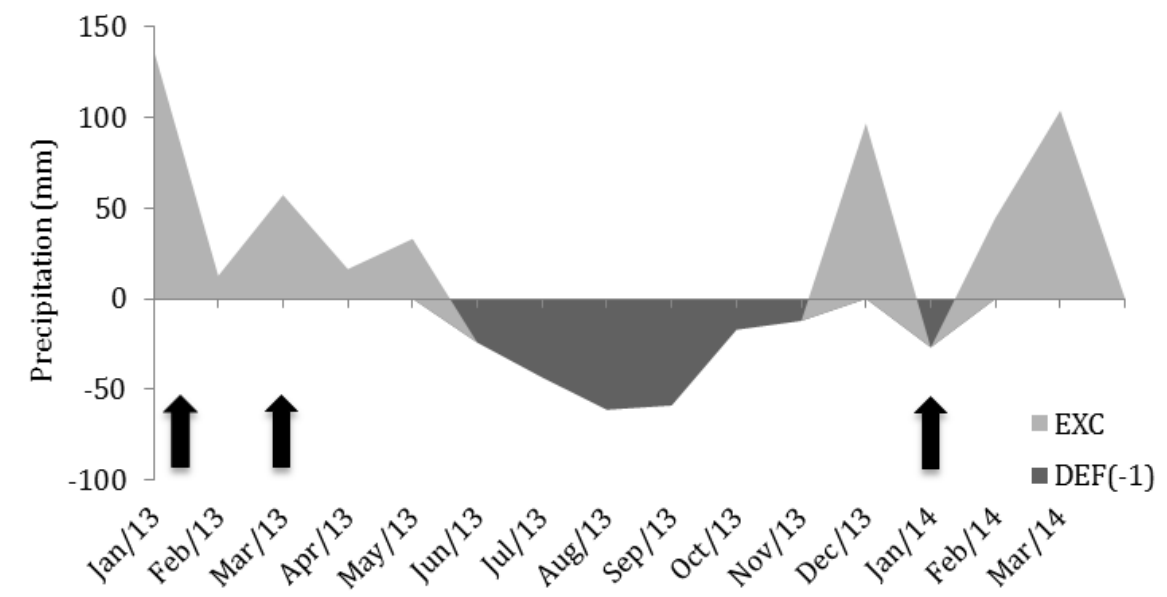

Figure 2. Balance of the water extract in the soil from January 2013 to March 2014. The arrows indicate when the fertilizations were made.

From January 2013 until 03/04/2013, all the paddocks were managed in continuous stocking and variable stocking rate using sheep to maintain the average heights of the pastures in four heights $(15,25,35$ and $45 \mathrm{~cm})$. The heights were measured weekly and controlled with addition or removal of sheep weighing $26 \mathrm{~kg}$ at the paddocks. On 03/04/2013, the 79-day deferment period began, ending on $06 / 21 / 2013$.

At that date, the occupational period of the deferred pastures began, which were managed in continuous stocking and fixed stocking rate. Twenty-eight sheep, crossbred Santa Inês x Dorper, approximatelly four months old, and initial average weight of $26 \mathrm{~kg}$ were used. The allocation of the animals to the paddocks was done randomly, to maintain the same initial stocking rate $(2.8 \mathrm{AU} / \mathrm{ha})$ in all paddocks. The grazing period of all deferred pastures was 96 days and its conclusion occurred on 09/25/2013, which was the transition between late winter and early spring.

Pastures initially deferred with 15,25 and $35 \mathrm{~cm}$ were at low $(15.1 \mathrm{~cm}$ and $4,600 \mathrm{~kg} / \mathrm{ha} D M)$, medium $(23.2 \mathrm{~cm}$ and $5,940 \mathrm{~kg} / \mathrm{ha} \mathrm{DM})$ and high $(31.4 \mathrm{~cm}$ and $7,640 \mathrm{~kg} / \mathrm{ha} \mathrm{DM})$ heights, respectively. The pasture with $45 \mathrm{~cm}$ at the beginning of the deferment presented values of height $(31.3 \mathrm{~cm})$ and forage mass $(7,200 \mathrm{~kg} / \mathrm{ha}$ of DM) similar to deferred pasture with an initial height of $35 \mathrm{~cm}$. For this reason, to cause a difference in the conditions of the 35 and $45 \mathrm{~cm}$ deferred pastures, the $145 \mathrm{~cm}$ pastures were mowed to $8 \mathrm{~cm}$ on $09 / 27 / 2013$, and the forage 
was not removed from the paddocks. Thus, it was possible to obtain four grazing conditions at the end of winter (low, medium, high and high/mowed), which had their characteristics evaluated during the beginning, middle and end of the grazing period, occurring in the spring and in the beginning of summer.

In this study, the treatments corresponded to four conditions of deferred pastures at the end of winter: low $(15.1 \mathrm{~cm}$ and $4,600 \mathrm{~kg} / \mathrm{ha} \mathrm{DM})$, medium $(23.2 \mathrm{~cm}$ and $5,940 \mathrm{~kg} / \mathrm{ha} \mathrm{DM})$, high $(31.4 \mathrm{~cm}$ and $7,640 \mathrm{~kg} / \mathrm{ha}$ of $\mathrm{DM})$ and high/mowed $(31.3 \mathrm{~cm}$ and $7,200 \mathrm{~kg} / \mathrm{ha}$ of DM mowed to $8 \mathrm{~cm})$. The experiment was conducted in a split plot design and in a completely randomized design, with three replications. The four pasture conditions at the end of the deferred grazing period in winter corresponded to the plots and the grazing periods (beginning, middle and end) in the spring and summer were the subplots.

From 09/27/2013, low, medium, high, and high/mowed pastures remained without animals for 46, 42, 14 and 44 days, respectively, until reaching $30 \mathrm{~cm}$, when the grazing period began, until 04/02/2014. During the grazing period, all pastures were managed in continuous stocking and variable stocking rate, in order to maintain an average height of $25 \mathrm{~cm}$. The animals used in this period were Santa Inês x Dorper crossbred sheep, with an average body weight of $30 \mathrm{~kg}$, which had unrestricted access only to mineral salt.

To control the pasture's heights, adjustments in the animal stocking rate were made, using the put and take method, with two groups of animals: tests and equilibrium. The test animals consisted of two sheep per paddock, and remained in the area throughout the experiment. The equilibrium animals were placed or removed from the paddocks when the average height of the pasture was above or below, respectively, of the recommended height.

Measurement of the pasture's heights were performed weekly, at 30 points of each experimental unit using a graded ruler and, following a zigzag path, taking as a criterion the distance from the soil surface to the apex of the living leaf located higher in the canopy.
At the beginning $\left(1^{\text {st }}\right.$ week $)$, middle $\left(45^{\text {th }}\right.$ day) and end (last week) of the grazing period, all pasture evaluations were performed. In order to determine the forage mass of the pastures, cuttings were made at ground level and all tillers contained within a square of $0.25 \mathrm{~m}^{2}$ were collected, in three representative areas of the pasture by paddock. Each sample was weighed and subdivided into two parts. One of the subsamples was weighed and wrapped in a paper bag and placed in the air-forced oven at $65^{\circ} \mathrm{C}$ for 72 hours, when it was again weighed, in order to estimate the total forage mass of the grass. The total forage volume density ( $\mathrm{kg} / \mathrm{ha} . \mathrm{cm} \mathrm{DM})$ was calculated by dividing the forage mass by the average canopy height.

The other sub-sample was separated into a live leaf blade, living stem and dead material. The inflorescence and green leaf sheath were incorporated into the live stem fraction. The part of the leaf blade that did not show signs of senescence was considered live leaf. On the other hand, the parts of the stem and the leaf blade that were senescent, with yellowing or, necrosis of the organ, were incorporated into the fraction of dead material. After separation, the components were weighed, oven dried and again weighed. Posteriorly, the percentages of the morphological components in the forage were estimated.

A sample of forage per paddock was also collected, trying to simulate the morphological composition of the forage consumed by the animals (Euclides et al., 1992). A single trained person performed these samplings by observing how the animals pluck the forage. Each simulated grazing sample was separated into the same morphological components described above for the grass samples. Subsequently, the morphological components were dried in an airforced oven at $65^{\circ} \mathrm{C}$ for 72 hours and weighed to obtain the relative participation of each morphological component in the forage.

The apparent selectivity index (ASI) done by the animals in relation to the morphological components of the pasture was calculated according to Santos et al. (2016).

At the beginning of the grazing period, all animals were weighed after 15 hours of a solidfasting period. Another weighing was performed at the end of the experimental period. Thus, the 
individual performance was calculated by the difference in the weight of the test animals between the beginning and the end of the evaluation period, considering the number of days of the evaluation period.

The length of stay of the equilibrium animals in each paddock was recorded. At the end of the experiment, it was possible to calculate the stocking rate in each paddock, expressed in AU/ha (animal unit $=450 \mathrm{~kg}$ ), with the number of days of stay of the animals. The production per unit of area, expressed in $\mathrm{kg} / \mathrm{ha}$, was calculated by the animal performance product (kg/animal.day) and the number of days.animal/ha.

The average daily weight gain, the stocking rate, and the animal production per unit of area were determined for the whole grazing period, and not divided into the beginning, middle and end, as was done for the other variables. Data were submitted to analysis of variance and the means comparison was performed by the Tukey test at the level of $5 \%$ probability of occurrence of type I error.

Table 1. Pasture characteristics, simulation samples and apparent selectivity index of sheep in pastures with marandu palisadegrass in spring and summer, according to the pasture condition at the end of winter

\begin{tabular}{cccccc}
\hline \multirow{2}{*}{ Characteristics } & \multicolumn{4}{c}{ Pasture condition at the end of winter* } & \multirow{2}{*}{ SEM } \\
\cline { 2 - 5 } & Low & Medium & High & High/mowed & \\
\hline Height $(\mathrm{cm})$ & $24.2 \mathrm{~b}$ & $26.9 \mathrm{a}$ & $22.6 \mathrm{c}$ & $24.2 \mathrm{~b}$ & 0.9 \\
LLB in AF & $28.2 \mathrm{~b}$ & $29.6 \mathrm{~b}$ & $22.4 \mathrm{c}$ & $34.3 \mathrm{a}$ & 2.5 \\
LS in AF & $23.4 \mathrm{a}$ & $24.6 \mathrm{a}$ & $21.5 \mathrm{a}$ & $26.9 \mathrm{a}$ & 1.1 \\
DT in AF & $48.4 \mathrm{~b}$ & $45.8 \mathrm{~b}$ & $56.2 \mathrm{a}$ & $38.8 \mathrm{c}$ & 3.6 \\
LLB in GS & $78.2 \mathrm{a}$ & $73.3 \mathrm{~b}$ & $72.4 \mathrm{~b}$ & $79.0 \mathrm{a}$ & 1.7 \\
LS in GS & $10.1 \mathrm{a}$ & $12.1 \mathrm{a}$ & $9.2 \mathrm{a}$ & $10.4 \mathrm{a}$ & 0.6 \\
DT in GS & $11.7 \mathrm{c}$ & $14.6 \mathrm{~b}$ & $18.4 \mathrm{a}$ & $10.6 \mathrm{c}$ & 1.7 \\
ASI of LS & $0.4 \mathrm{a}$ & $0.5 \mathrm{a}$ & $0.4 \mathrm{a}$ & $0.4 \mathrm{a}$ & 0.0 \\
ASI of DT & $0.3 \mathrm{a}$ & $0.3 \mathrm{a}$ & $0.3 \mathrm{a}$ & $0.3 \mathrm{a}$ & 0.0 \\
\hline
\end{tabular}

*Low: $15.1 \mathrm{~cm}$ and 4,600kg/ha of DM; Medium: $23.2 \mathrm{~cm}$ and 5,940kg/ha of DM; High: $31.4 \mathrm{~cm}$ and 7,640kg/ha of DM; High/mowed: $31.3 \mathrm{~cm}$ and 7,200kg/ha of DM. SEM: standard error mean; LLB: live leaf blade $(\%)$; AF: available forage; LS: live stem (\%); DT: dead tissue (\%); GS: sample of grazing simulation; ASI apparent selectivity index. Means followed by different letters differ by Tukey test $(\mathrm{P}<0.05)$.

The percentage of live leaf blade was greater in the high/mowed pastures, intermediate in the medium and low pastures, and lower in the high pastures. Conversely, the percentage of dead tissue was greater in the high pastures and lower in the high/mowed pastures (Table 1). This happened because the mowing promoted the elimination of much of the old forage, allowing the renewal of tillers in the pasture. Thus, there was more expressive participation of the young and vegetative tillers after mowing (Souza et al., 2015), which presented the greatest elongation and leaf appearance rates (Paiva et al., 2011), and has better morphological composition (Santos et al., 2010). On the other hand, the high marandu palisadegrass at the end of winter promoted greater shading at the base of the plants, inhibiting tillering (Santos et al., 2011); which generated a pasture with high percentage 
of dead tissues during spring and early summer (Souza et al., 2015).

As a consequence of the better morphological composition of the pasture, the animals consumed greater percentage of live leaf blade in the low and high/mowed pastures and greater percentage of dead tissue in the high pastures (Table 1).

Because the high/mowed pastures did not have high amount of forage from the previous winter, when compared to the other pastures, it presented greater percentage of live leaf blade (Table 1). In fact, the high/mowed pastures also showed lower apparent leaf selectivity index (ASI) of the lower leaf at the beginning of the grazing period (Table 2 ), in relation to the other pasture conditions. On the other hand, the high pasture, because of its poor morphological composition (Table 1), showed higher ASI of LLB (Table 2), indicating that the animal had a higher selection of this component at the beginning of the grazing period.

Table 2. Pasture characteristics and apparent selectivity index of sheep in pastures with marandu palisadegrass in spring and summer, according to the pasture condition at the end of winter

\begin{tabular}{|c|c|c|c|c|c|}
\hline \multirow{2}{*}{ Period } & \multicolumn{4}{|c|}{ Pasture condition at the end of the winter * } & \multirow{2}{*}{ SEM } \\
\hline & Low & Medium & High & High/mowed & \\
\hline \multicolumn{6}{|c|}{ Forage mass $(\mathrm{kg} / \mathrm{ha}$ of $\mathrm{DM})$} \\
\hline Beginning & $3981 \mathrm{aA}$ & $4796 \mathrm{aA}$ & $4702 \mathrm{aA}$ & $2270 \mathrm{bB}$ & 584,8 \\
\hline Half & $3660 \mathrm{aA}$ & $3700 \mathrm{aB}$ & $3964 \mathrm{aB}$ & $3708 \mathrm{aA}$ & 69,5 \\
\hline End & $3724 \mathrm{aA}$ & $3915 \mathrm{aB}$ & $3644 \mathrm{aB}$ & $3929 \mathrm{aA}$ & 70,7 \\
\hline \multicolumn{6}{|c|}{ Volumetric density of the forage (kg/ha.cm de MS) } \\
\hline Beginning & $165 \mathrm{aA}$ & $173 \mathrm{aA}$ & $182 \mathrm{aAB}$ & $92 \mathrm{bC}$ & 20,6 \\
\hline Half & $141 \mathrm{bA}$ & $133 \mathrm{bB}$ & $165 \mathrm{aB}$ & $145 \mathrm{bB}$ & 6,8 \\
\hline End & $166 \mathrm{bA}$ & $156 \mathrm{bAB}$ & $205 \mathrm{aA}$ & $175 \mathrm{bA}$ & 10,6 \\
\hline \multicolumn{6}{|c|}{ Apparent selectivity index of live leaf blade } \\
\hline Beginning & $3.9 \mathrm{bA}$ & $4.3 \mathrm{bA}$ & $5.4 \mathrm{aA}$ & $2.6 \mathrm{cA}$ & 0.6 \\
\hline Half & $2.3 \mathrm{aB}$ & $2.0 \mathrm{aB}$ & $3.1 \mathrm{aB}$ & $2.5 \mathrm{aA}$ & 0.2 \\
\hline End & $2.4 \mathrm{aB}$ & $1.9 \mathrm{aC}$ & $2.2 \mathrm{aC}$ & $1.9 \mathrm{aA}$ & 0.1 \\
\hline
\end{tabular}

*Low: $15.1 \mathrm{~cm}$ and 4,600kg/ha of DM; Medium: $23.2 \mathrm{~cm}$ and 5,940kg/ha of DM; High: $31.4 \mathrm{~cm}$ and $7,640 \mathrm{~kg} / \mathrm{ha}$ of DM; High/mowed: $31.3 \mathrm{~cm}$ and $7,200 \mathrm{~kg} / \mathrm{ha}$ of DM. SEM: standard error mean. Means followed by different letters differ by Tukey test $(\mathrm{P}<0.05)$.

There was a reduction in the average height of the medium pastures at the end of the grazing period (Table 3 ), as a function of the hot days observed in January 2014 (Figure 2). In this period, all the equilibrium animals were removed from the paddocks, but the test animals were maintained for the measurement of animal production.

At the beginning of the grazing period, the high/mowed pasture had a lower forage mass and lower volumetric density, while in the middle and at the end there was no difference in forage mass among pastures (Table 2). After mowing, due to the high amount of dead forage on the plants, there may have been a lower incidence of light on the basal buds, with consequent delay of tillering (Calvano et al., 2011; Santos et al., 2011). In addition, with the mowing, many dead and old tillers were eliminated from the forage canopy. These factors may have reduced the mass and density of forage present at the beginning of the grazing period. However, as the grazing period passes (middle and end), the high/mowed pasture probably restored its population density of tillers, which maintained its total mass and forage volume density at levels similar to the other pastures (Table 2).

The forage volumetric density remained high throughout the grazing period (Table 2), due to the high amount of leaves and, especially, dead 
stems from winter, which remained mixed with the young tillers from spring (Table 1).

At the beginning of the grazing period, the pastures presented dead forage residue from the previous winter, which justifies the worst morphological composition (lower percentages of live leaf and live stem and higher percentage of dead tissue) at the beginning and in the middle and end of the grazing period (Table 3).

Table 3. Pasture characteristics, grazing simulation samples and apparent selectivity index of sheep in pastures with marandu palisadegrass, according to the grazing period in the spring and summer

\begin{tabular}{ccccc}
\hline \multirow{2}{*}{ Characteristics } & \multicolumn{3}{c}{ Grazing period } & SEM \\
\cline { 2 - 5 } & Beginning & Half & End & 1.3 \\
Height (cm) & $25.6 \mathrm{a}$ & $25.9 \mathrm{a}$ & $21.9 \mathrm{~b}$ & 2.8 \\
LLB in AF & $23.2 \mathrm{~b}$ & $30.6 \mathrm{a}$ & $32.1 \mathrm{a}$ & 2.1 \\
LS in AF & $20.2 \mathrm{~b}$ & $24.7 \mathrm{a}$ & $27.5 \mathrm{a}$ & 4.9 \\
DT in AF & $56.7 \mathrm{a}$ & $44.8 \mathrm{~b}$ & $40.4 \mathrm{~b}$ & 6.2 \\
LLB in GS & $87.4 \mathrm{a}$ & $73.9 \mathrm{~b}$ & $66 \mathrm{c}$ & 3.1 \\
LS in GS & $4.5 \mathrm{~b}$ & $12 \mathrm{a}$ & $14.8 \mathrm{a}$ & 3.2 \\
DT in GS & $8.1 \mathrm{c}$ & $14.2 \mathrm{~b}$ & $19.2 \mathrm{a}$ & 0.1 \\
ASI of LS & $0.2 \mathrm{~b}$ & $0.5 \mathrm{a}$ & $0.5 \mathrm{a}$ & 0.1 \\
ASI of DT & $0.1 \mathrm{c}$ & $0.3 \mathrm{~b}$ & $0.5 \mathrm{a}$ & \\
\hline
\end{tabular}

SEM: standard error mean; LLB: live leaf blade (\%); AF: available forage; LS: live stem (\%); DT: dead tissue (\%); GS: sample of grazing simulation; ASI apparent selectivity index. Means followed by different letters differ by Tukey test $(\mathrm{P}<0.05)$.

The worst morphological composition of the pastures at the beginning of the grazing period did not worsen the morphological composition of the animal grazing simulation sample in this period, which had greater percentage of live leaf blade and lower percentage of stem and dead tissue, when compared to the half and to the end of the grazing period (Table 3 ). At the beginning of the grazing period, due to regrowth, the pastures presented greater amount of live leaf in the upper stratum, which is characteristic of pastures under intermittent stocking in the pregrazing condition (Fonseca et al., 2012). Thus, the sheep easily consumed the live leaves. After the consumption of these live leaves, during the days of occupation, the morphological composition of the animal grazing simulation sample worsened. In the middle and end of the grazing period, pastures contained morphological components from regrowth in spring and summer, which were interspersed with older and senescent tissues, still remaining in winter. This structure, typical of continuous stocking management (Euclides et al., 2014), resulted in greater percentages of live stem and dead tissue, as well as a lower percentage of live leaf blade with the advancement of the grazing period (Table 2).
The ASI of dead tissue and live stem generally showed increasing values over the course of the grazing period (Table 3), indicating that sheep found it difficult to reject less preferred components. On the other hand, leaf litter ASI decreased in the low, medium, and high pastures from the beginning to the end of the grazing period (Table 3), due to the increase of this component in the pastures and the reduction of the percentage of LLB in the grazing simulation samples during the grazing period (Table 3 ). Thus, with the improvement of the morphological composition of the pasture, sheep did not present difficulties in selecting a diet with a high percentage of LLB.

The structural characteristics of the pasture determine the selective capacity and performance of grazing animals (Poppi et al., 1987). In this context, sheep performance was greater in the low pasture, intermediate in the high/mowed pasture and lower in the medium and high pastures (Table 4). This result is a consequence of the better morphological composition of the grazing simulation samples obtained in the low and high/mowed pastures compared to the medium and high pastures (Table 1). 
Sheep production during...

Table 4. Sheep production in pastures with marandu palisadegrass in spring and summer, according to the pasture condition at the end of the winter after its use under deferred grazing

\begin{tabular}{lccccc}
\multirow{2}{*}{ Characteristics } & \multicolumn{4}{c}{ Pasture condition at the end of winter* } & \multirow{2}{*}{ SEM } \\
\cline { 2 - 5 } & Low & Medium & High & High/mowed & \\
\hline PF & $130 \mathrm{a}$ & $60 \mathrm{c}$ & $60 \mathrm{c}$ & $80 \mathrm{~b}$ & 16,5 \\
SR (AU/ha) & $1,9 \mathrm{ab}$ & $2,1 \mathrm{a}$ & $1,6 \mathrm{~b}$ & $1,8 \mathrm{~b}$ & 0,1 \\
DGP (day) & $84 \mathrm{~b}$ & $88 \mathrm{~b}$ & $116 \mathrm{a}$ & $86 \mathrm{~b}$ & 7,5 \\
AP (kg/ha.day) & $4,3 \mathrm{a}$ & $2,7 \mathrm{~b}$ & $1,7 \mathrm{c}$ & $2,5 \mathrm{~b}$ & 0,5 \\
\hline
\end{tabular}

*Low: $15.1 \mathrm{~cm}$ and 4,600kg/ha of DM; Medium: $23.2 \mathrm{~cm}$ and 5,940kg/ha of DM; High: $31.4 \mathrm{~cm}$ and 7,640kg/ha of DM; High/mowed: $31.3 \mathrm{~cm}$ and $7,200 \mathrm{~kg} / \mathrm{ha}$ of DM SEM: standard error mean; PF: animal performance (g/animal.day); SR: stocking rate; DGP: duration of grazing period; AP: animal production per unit of area; Means followed by different letters differ by Tukey test $(\mathrm{P}<0.05)$.

On the other hand, the high and medium pastures were characterized by a high percentage of dead forage in the available forage and in the animal grazing simulation sample (Table 1), which may have limited sheep performance, since dead forage, especially stems, have low nutritional value (Santos et al., 2008).

The high/mowed pastures, although with a morphological composition in the animal grazing simulation sample similar to the low pasture (Table 1), resulted in lower animal performance than the low pasture (Table 4). It is likely that the low mass and volume density of forage in high /mowed pastures during the beginning of the grazing period (Table 2) has limited sheep performance.

The stocking rate was greater in the medium pasture, compared to the high and high/mowed pastures (Table 4), possibly due to the greater forage yield of the medium pasture. Forage production and, in fact, the stocking rate, may have been lower in the high pasture, due to the large amount of dead forage in the canopy, which may have limited tillering (Santana et al., 2014). Similarly, in the high/mowed pastures, tillering and forage production may also have been delayed at the beginning of the grazing period due to the high forage mass cut, which shaded the base of the plants.

The high pasture had a longer grazing period (Table 4), since it presented higher heights at the end of the winter and, therefore, its grazing period occurred earlier to the other grazing conditions, to guarantee the control of the canopy height.
The low performance of the sheep, concomitantly to the lower stocking rate of the high pasture contributed for their inferior animal production per unit area, in comparison to the other pastures. On the other hand, in the low pasture, the greatest performance of the animals, added to the high stocking rate, were determinants of the high production per unit area. The medium and high/mowed pasture presented animal production per unit of intermediate area to low and high pastures (Table 4).

The data of this study show the advantage of low deferred pasture at the end of winter, in order to improve the structure of the marandu palisadegrass and, consequently, the animal production from spring. However, when marandu palisadegrass is high at the end of winter, mowing improves structure and animal performance in spring and summer. The decision to use the mowing should be made counterbalancing the costs of this technique with its benefits, in terms of the income obtained with the additional livestock production in the pasture compared to the non-planted pasture.

\section{CONCLUSIONS}

Compared to the high pasture $(31.4 \mathrm{~cm}$ and $7,640 \mathrm{~kg} / \mathrm{ha} \mathrm{DM})$, pastures deferred at low heights $(15.1 \mathrm{~cm}$ and $4,600 \mathrm{~kg} / \mathrm{ha} \mathrm{DM})$ at the end of winter show better structure and greater sheep production from spring. The mowing of the marandu palisadegrass at $8 \mathrm{~cm}$ with high forage mass $(7,200 \mathrm{~kg} / \mathrm{ha}$ of DM) at the end of winter improves its structure and increases animal production during spring and early summer. 


\section{REFERENCES}

CALVANO, M.P.C.A.; EUCLIDES, V.P.B.; MONTAGNER, D.B. et al. Tillering and forage accumulation in Marandu grass under different grazing intensities. Rev. Ceres, v.58, p.781-789, 2011.

CANTARUTTI, R.B.; MARTINS, C.E.; CARVALHO, M.M. et al. Pastagens. In: RIBEIRO, A.C.; GUIMARÃES, P.T.G.; ALVAREZ, V.H. Recomendações para o uso de corretivos e fertilizantes em Minas Gerais - $5^{\text {a }}$ aproximação. Viçosa-MG: CFSEMG/UFV, 1999. p.332-341.

CANTO, M.W.; JOBIM, C.C.; CECATO, U. et al. Acúmulo de forragem e perfilhamento em capim Tanzânia, Panicum maximum Jacq., diferido após pastejo em diferentes alturas. Acta Sci. Anim. Sci., v.24, p.1087-1092, 2002.

EUCLIDES, V.P.B.; FLORES, R.; MEDEIROS, R.N. et al. Diferimento de pastos de braquiária cultivares Basilisk e Marandu, na região do Cerrado. Pesqui. Agropecu. Bras.,v.42, p.273280, 2007.

EUCLIDES, V.P.B.; MACEDO, M.C.M.; OLIVEIRA, M.P. Avaliação de diferentes métodos de amostragem para estimar o valor nutritivo de forragens sob pastejo. Rev. Bras. Zootec., v.21, p.691-702, 1992.

EUCLIDES, V.P.B.; MONTAGNER, D.B.; BARBOSA, R.A. et al. Manejo do pastejo de cultivares de Brachiaria brizantha (Hochst) Stapf e de Panicum maximum Jacq. Rev. Ceres, v.61, p.808-818, 2014.

FONSECA, L.; MEZZALIRA, J.C.; BRAMM, C. et al. Management targets for maximising the short-term herbage intake rate of cattle grazing in Sorghum bicolor. Livest. Sci., v.145, p.205-211, 2012.

LACA, E.A.; LEMAIRE, G. Measuring sward structure. In: T'MANNETJE, L.; JONES, R.M. (Eds.). Field and laboratory methods for grassland and animal production research. New York: CABI, 2000. p.103-122.
NAVE， R.L.G.; PEDREIRA， C.G.S.; PEDREIRA, B.C. Nutritive value and physical characteristics of Xaraes palisadegrass as affected by grazing strategy. S. Afr. J. Anim. Sci., v.40, p.285-293, 2010.

PAIVA, A.J.; SILVA, S.C.; PEREIRA, L.E.T. et al. Morphogenesis on age categories of tillers in marandu palisadegrass. Sci. Agric., v.68, p.626631, 2011.

POPPI, D.P.; HUGHES, T.P.; L'HUILLIER, P.J. Intake of pasture by grazing ruminants. Livestock feeding on pasture. Hamilton: New Zealand Society of Animal Production, 1987. p.55-64.

SANTANA, S.S.; FONSECA, D.M.; SANTOS, M.E.R. et al. Initial height of pasture deferred and utilized in winter and tillering dynamics of signal grass during the following spring. Acta Sci. Anim. Sci., v.36, p.17-23, 2014.

SANTOS, M.E.R.; FONSECA, D.M.; BALBINO, E.M. et al. Características estruturais de perfilhos vegetativos e reprodutivos em pastos diferidos de capim-braquiária. Cienc. Anim. Bras., v.11, p.492-502, 2010.

SANTOS, M.E.R.; FONSECA, D.M.; EUCLIDES, V.P.B. et al. Valor nutritivo da forragem e de seus componentes morfológicos em pastagens de Brachiaria decumbens diferida. Bol. Ind. Anim., v.65, p.303-311, 2008.

SANTOS, M.E.R.; FONSECA, D.M.; GOMES, V.M. et al. Capim-braquiária sob lotação contínua e com altura única ou variável durante as estações do ano: dinâmica do perfilhamento. Rev. Bras. Zootec., v.40, p.2332-2339, 2011.

SANTOS, M.E.R.; FONSECA, D.M.; SOUSA, D.O.C. Seletividade aparente de bovinos em pastos de capim-braquiária sob períodos de diferimento. Arq. Bras. Med. Vet. Zootec., v.68, p.1655-1663, 2016.

SOUZA, D.O.C.; FERNANDES, W.B.; SILVA, G.F. et al. A roçada do capim-marandu alto no fim do inverno melhora a estrutura do pasto no início do verão. Encicl. Biosfera, Centro Cient. Conhecer, v.11, p.12-22, 2015. 